PEDULI: Jurnal Ilmiah Pengabdian Pada Masyarakat, 2021, Vol.5, No.2 ISSN: 25974653. EISSN:25974688

http://peduli.wisnuwardhana.ac.id/index.php/peduli/index

\title{
PELATIHAN MANAJEMEN KEWIRAUSAHAAN BUMDES SEBAGAI PENGELOLA EKOWISATA HUTAN DESA GALUNGAN KABUPATEN BULELENG
}

\author{
Ni Made Wahyuni ${ }^{1}$, I Made Sara ${ }^{2}$ \\ ${ }^{1,2}$ Universitas Warmadewa \\ mdwahyuni17@gmail.com¹, saramade.25a@gmail.com²
}

\begin{abstract}
Abstrak: Human resources are needed in developing the competitiveness. Galungan Village, Sawan District, Bali Province with assets in the form of village forests surrounded by mountains and beautiful natural scenery, cool air, jogging tracking, tours to waterfalls, rivers and hundreds of hundreds of years old trees are very worthy of being preserved as ecotourism icons. Based on the Decree of the Governor of Bali Number 2017/03-L/HK.2015 concerning the granting of village forest management rights, the management of village forest work areas is carried out by Rural-Owned Enterprises (BUMDes). The problem is that the performance of BUMDes: (1) low entrepreneurial intentions, attitudes, behavior; (2) low management practices (Aryaningsih, 2020). Business performance influenced by management, entrepreneurial attitudes. Objectives: 1) improve the implementation of entrepreneurial 2) improve the dissemination of management knowledge for institutional strengthening of Rural-Owned Enterprises. The method of implementing community service with a participatory method is through lectures, training, education that allows the service team to interact, communicate intensively and directly with the community and their business activities. Activities contribute to increasing knowledge and skills of BUMDes entrepreneurial management of village forest ecotourism. Suggestions, BUMDes managers and stakeholders pay more attention to management and entrepreneurial action in managing village forest ecotourism.
\end{abstract}

Keywords: Ecotourism, Rural-Owned Enterprises, Management, Entrepreneurship

\section{PENDAHULUAN}

Desa Galungan adalah sebuah desa di Kecamatan Sawan Kabupaten Buleleng, Bali, Indonesia terletak di ketinggian $1000 \mathrm{~m}$ dpl dengan potensi sumber daya alam (SDA) berupa pengunungan dan pemandangan alam yang indah, hawa sejuk, jogging tracking, wisata menuju air terjun, sungai dan ratusan pohon tua berusia ratusan tahun yang layak dilestarikan serta sumber daya manusia dengan segala keunikan dan kemampuan. Posisi desa memiliki nilai strategis dalam pembangunan negara karena desa mampu cepat teridentifikasi permasalahan masyarakat (Sidik, 2015).

Kegiatan pembangunan desa memiliki tujuan untuk kemajuan perekonomian desa. Undang_Undang Nomor 6 Tahun 2014 tentang desa menjadi landasan hukum pembangunan desa, memberikan peluang dan kemandirian secara signifikan mengelola sumber daya alam (SDA), kearifan lokal dan sumber daya lainnya. Konteks kualitas lembaga ekonomi yang sesuai mendukung alokasi dan pengelolaan sumber daya serta keberadaan kewirausahaan. Lembaga ekonomi dibutuhkan dalam membangun transaksi komersial dalam ekonomi tertentu. Kualitas lembaga ekonomi menentukan operasional di sektor swasta maupun publik (Fennimore \& Sementelli, 2016).

BUMDes menjadi wadah mendorong pembangunan memajukan desa (Agunggunanto, Arianti, Kushartono, \& Darwanto, 2016). Pada dasarnya, fungsi BUMDes sebagai badan usaha komersial dan sosial yang menampung kegiatan ekonomi dan dikelola secara profesional menjadi salah satu pilar kemandirian kegiatan ekonomi desa dengan tetap 
bersandar pada keaslian potensi desa (Febryani et al., 2019). Secara umum, tujuan pendirian BUMDes secara lengkap tertuang dalam Permendagri Nomor 4 Tahun 2015 sebagai berikut: 1) meningkatkan perekonomian desa; 2) mengoptimalkan aset desa; 3) meningkatkan usaha-usaha masyarakat; 4) meningkatkan pendapatan asli desa; 5) menjadi tulang punggung pertumbuhan dan pemerataan ekonomi desa; 6) meningkatkan pengelolaan potensi desa disesuaikan dengan kebutuhan masyarakat; 7) membuka lapangan kerja; 8) menciptakan peluang dan jaringan pasar; dan 9) meningkatkan kesejahteraan masyarakat. Badan Usaha Milik Desa (BUMDES) adalah lembaga ekonomi diciptakan untuk menampung dan mendorong aktivitas peningkatan pendapatan masyarakat, baik yang berkembang menurut budaya setempat, adat, maupun kegiatan perekonomian yang mana masyarakat mengelola sumber daya dan potensi wilayah tersebut. Pengembangan BUMDes yang telah berdiri diharapkan dapat berfungsi sesuai dengan peranannya. Jika BUMDes dikelola secara terarah dan professional, maka diharapkan mampu mencapai misi dan tujuan baik ekonomi dan sosial. Terbentuknya BUMDes dalam upaya mengatasi solusi atas permasalahan-permasalahan ekonomi seperti kemiskinan, distribusi pendapatan tidak merata antara kota dan desa, dan kesejahteraan masyarakat desa. Lembaga ekonomi desa diharapkan menjadi penggerak dan pendorong geliat ekonomi desa. Prakarsa pemerintah menetapkan keberadaan BUMDes bersama-sama masyarakat dalam mengelola potensi desa dengan kreatif dan inovatif, membentuk desa yang produktif dengan tetap memperhatikan aspek lingkungan, ekonomi, dan sosial berkelanjutan di pedesaan. Keberadaan BUMDesa di Desa Galungan antara lain untuk pengelolaan sumber daya dengan unit usaha yaitu kelompok sadar wisata (pokdarwis) ekowisata hutan desa.

Hutan Desa Galungan seluas 712 hektar berhak dikelola berdasarkan Hak Pengelolaan Hutan berdasarkan Keputusan Kementerian Kehutanan Republik Indonesia Nomor 529/Menhut-II/2010, tanpa mengubah fungsi kawasan sebagai hutan lindung. BUMDes Galungan pengelola ekowisata dengan sumber daya yang dimiliki, dengan kemampuan manajemen diharapkan mampu menyokong ekonomi desa. Namun, hasil survey menemukan tantangan \& permasalahan wirausaha, pengelolaan ekowisata hutan desa oleh BUMDes adalah (1) rendahnya keterampilan manajemen kewirausahaan; (2) kurang mampu mengidentifikasi peluang; (3) minimnya orientasi pasar sebagai implementasi konsep pemasaran (Aryaningsih, Suari, Darmayasa, \& Utthavi, 2021). Fakta bisnis inilah yang menjadi latar belakang dilaksanakannya program pengabdian kepada masyarakat di Desa Galungan.

BUMDes dibentuk sebagai lembaga ekonomi pengelola sumber daya alam dan sumber daya lain di desa. BUMDEs Galungan ikut serta mengembangkan ekowisata hutan desa dengan unit usaha pokdarwis (kelompok sadar wisata). Permasalahan yang dihadapi pengelola BUMDes dengan unit kelompok sadar wisata (pokdarwis) adalah penanganan sumber daya alam dan SDM nya memerlukan sentuhan keterampilan berbasis manajemen kewirausahaan, sehingga mampu menciptakan kepuasan pelanggan dan kinerja usaha superior. Manajemen BUMDes pengelola hutan desa dan pemandu wisata banyak yang telah berpengalaman di bidang pariwisata di kota-kota besar seperti di Jakarta, Denpasar, bahkan di luar negeri. Jadi mereka telah memiliki pengalaman di bidang yang terkait dengan pariwisata. Namun, ketika pengetahuan mereka diterapkan di desa dalam pengelolaan hutan desa, masih ada gesekan antara perantau dan pengetahuan masyarakat desa dalam hal keterampilan baik SDM, keuangan, dan bahkan keterampilan personal. 
Perlu adanya sentuhan wawasan, pengetahuan, keterampilan sehingga kompetensi mereka dalam pengelolaan lembaga ekonomi seperti BUMDes mampu mendorong pertumbuhan ekonomi masyarakat Galungan.

Manajemen kewirausahaan dapat dilihat sebagai pencarian ide baru, wahana dan implementasi inovasi menuju praktik pengelolaan organisasi publik yang memberikan nilai baru pada berbagai pemangku kepentingan dan konsumen yang mereka layani (Zampetakis $\&$ Moustakis, 2007). Penerapan model manajemen kewirausahaan ke dalam organisasi milik publik dapat dikaitkan dengan pencapaian tujuan individu dan ekonomi. Model manajemen usaha yang diterapkan dimodifikasi dan disesuaikan dengan tuntutan spesifik sektor publik. Ada hubungan yang kuat antara kewirausahaan dan inovasi. Konsep inovasi sebagai penciptaan nilai diperluas dengan makna proses, memasukkan praktik baru, dan strategi baru (misal tujuan organisasi yang baru), atau hal baru yang dirasakan untuk diadopsi BUMDes Galungan, termasuk dalam mengelola ekowisata hutan desa.

BUMDes membutuhkan penyuluhan, pendampingan dan pelatihan untuk mencapai kepuasan pelanggan dan pertumbuhan usaha(Sastri, Irianto, \& Wahyuni, 2021). Dengan demikian, solusi atas permasalahan menggunakan pendekatan manajemen dan kewirausahaan, di mana vitalitas kewirausahaan telah diakui sebagai faktor penting mengukur kemajuan ekonomi dan harapan di masa depan yang pada gilirannya menciptakan inovasi, lapangan kerja dan menjamin kesejahteraan. Isu manajerial kewirausahaan mitra dalam hal ini BUMDes dan pemangku kepentingan adalah melaksanakan pelatihan dengan kerjasama praktisi_akademisi. Kegiatan pengabdian melalui program pelatihan ini dilaksanakan dengan tujuan, supaya pengelola dan pihak yang bertanggung jawab pada usaha ekowisata hutan desa memahami bagaimana manajemen kewirausahaan dilaksanakan pada sektor swasta dan publik, sehingga mampu mencapai kesusesan berkelanjutan dari aspek sosial, ekologi, lingkungan dan ekonomi (profit).

Pelatihan didefinisikan sebagai tindakan pengalaman belajar yang mampu menciptakan pengetahuan teknis, adaperubahan perilaku individu dan meningkatkan kemampuan dalam menyelesaikan pekerjaan, mampu bertanggung jawab. Pelatihan sebagai strategi manajemen mampu mengatasi tantangan manajer /pengelola jika ingin meningkatkan kompetensi dan mencapai kesuksesan (MacPherson \& Jayawarna, 2007); (Thassanabanjong, Miller, \& Marchant, 2009). Kompetensi sebagai karakteristik mendasar seorang individu yang memiliki integrasi motif, sifat, keterampilan, pengetahuan, dan kemampuan untuk memulai usaha yang memungkinkan mencapai kinerja BUMDEs superior. Studi empiris yang dilakukan di Afrika Selatan menemukan bahwa, keterampilan dapat dipelajari dan disempurnakan melalui pengalaman dan praktik. Keterampilan menunjukkan kecakapan dalam menjalankan tugas dan dapat ditingkatkan melalui pelatihan, dan pengembangan, dan keterampilan disesuaikan dengan tugas yang dilakukan. Pelatihan penting untuk menstimulasi kewirausahaan. Pelatihan dalam bentuk seminar untuk memperoleh pengetahuan dan keterampilan baru untuk memecahkan masalah dan memastikan layanan berkualitas (Jayawarna, Macpherson, \& Wilson, 2007). Keterampilan yang dimiliki usahawan mengarahkan bisnis mereka pada keberlanjutan dan pertumbuhan. Perspektif teori modal manusia menegaskan, keterampilan adalah hasil investasi dalam pengalaman dan pendidikan. Semakin meningkat kesadaran akan pentingnya seorang manajer berinovasi pada organisasi. Seorang wirausahawan yang berinovasi membutuhkan 
keterampilan. Keterampilan tercipta melalui pengalaman, pelatihan, dan praktik. Keterampilan manajemen kewirausahaan mencerminkan kemahiran memahami tugas, kecakapan menerapkan pengetahuan dengan benar; kegiatan keterampilan yang dibutuhkan untuk mengubah ide menjadi peluang, memulai dan membangun keberhasilan menjalankan bisnis (Mamabolo, Kerrin, \& Kele, 2017).

Perusahaan mencari peluang pertumbuhan melalui kewirausahaan. Kewirausahaan bisa ditinjau dari aspek sikap, aspirasi yang berdampak pada ekonomi, dan aktivitas dikonseptualisasikan sebagai kerangka kerja integratif manajerial dan budaya dengan tiga wujud dimensi seperti proaktif mengejar peluang pasar, otonomi, inovatif ekploitasi ide baru, dan mampu menyatukan keunikan sumber daya yang dimiliki (Doran, McCarthy, \& O'Connor, 2018). Lingkungan kompetitif yang berubah cepat memberikan kesempatan wirausaha di lembaga ekonomi mengintegrasikan karakteristik wirausahawan di sektor publik. Organisasi milik masyarakat (publik) yang menerapkan jiwa wirausaha berupaya mengkompromikan nilai-nilai kewirausahaan seperti inovatif, kebebasan atau otonomi memungkinkan pertumbuhan organisasinya (Poon, Zhou, \& Chan, 2009).

Literatur ekonomi telah membahas kewirausahaan sebagai kunci penting kinerja usaha dan kesejahteraan. Kewirausahaan menentukan pembangunan. Dan, pembangunan identik ke arah perubahan, termasuk perubahan niat, perilaku, kepribadian, pengetahuan, dan keterampilan(Sardianou et al., 2016). Proses kewirausahaan dimulai dari identifikasi peluang ekonomi, pendidikan kewirausahaan, mengorganisasi dan mengoperasikan metode, pemasaran dan merangkum sumber daya (Costanza, 2019). Intensitas kewirausahaan dapat diamati dari kemampuan perusahaan proaktif dan fleksibel dalam mengelola sumber daya, cenderung dengan tindakan berisiko, berinovasi dalam proses, dan cenderung agresif mengejar perubahan ke arah yang lebih baik (Wahyuni \& Sara, 2020). Kewirausahaan memiliki potensi untuk berkembang di bidang nirlaba, sosial, dan sektor publik. Keuntungan yang dihasilkan oleh tindakan kewirausahaan di desa menguntungkan warga lokal, menyerap surplus tenaga kerja lokal, ekonomi lokal, pemerintah lokal dan berujung pada kesejahteraan masyarakat. Manajemen kewirausahaan merupakan keterampilan manajemen wirausahawan untuk mengarahkan kegiatan usahanya pada pertumbuhan dan kelangsungan hidup perusahaan (Gangi, 2017).

Perspektif manajerial fokus pada dampak keterlibatan praktik manajerial pelaku usaha untuk mengatasi lingkungan dinamis yang berkontribusi meningkatkan kegiatan bisnis. Di sisi lain, penetrasi kewirausahaan ditentukan oleh adopsi praktik manajemen yang relevan oleh pemangku kepentingan dan pengusaha. Penerapan praktik manajerial mempengaruhi efektivitas karakter kewirausahaan di suatu wilayah. Kesuksesan kewirausahaan dengan demikian ditentukan oleh perubahan pengelolaan yang efisien. Menghubungkan kewirausahaan dengan manajemen mendorong terciptanya cara baru yang inovatif dalam mengatur operasi bisnis untuk memanfaatkan peluang, pelestarian budaya lokal, reputasi, dan keuntungan ekonomi dari usaha mereka (Ionescu, 2016).

Hutan bisa ditinjau dari aspek sosial, ekonomi dan lingkungan merupakan sumber daya alam yang dimanfaatkan secara berkelanjutan di kawasan wilayah adminsitrasi desa sebagai muara kesejahteraan rakyat (Kuncoro \& Cahyani, 2018). Hutan desa sebagai aset negara yang dapat dikelola dan dimanfaatkan, namun tetap lestari dengan menetapkan pengelolaan pada lembaga masyarakat desa Pemerintah melalui Kementerian Pemerintah desa berperan mengakomodasi potensi desa tersebut dan pemenuhan kebutuhan warga 
desa, dengan memberikan dukungan besar pada lembaga ekonomi di desa. Peran pemerintah desa dalam optimalisasi kapasitas dan kegiatan ekonomi adalah dengan memprioritaskan lembaga ekonomi dalam hal ini, BUMDes untuk mengelola potensi desa berupa hutan desa(Nuranita, Dassir, \& Makkarennu, 2020). .

Tujuan PKM adalah untuk diseminasi aplikasi manajemen kewirausahaan dan sebagai bahan dan informasi untuk pengambilan keputusan untuk mengembangkan kompetensi pengelola BUMDes, aparat desa, desa adat, dan pemangku kepentingan yang terlibat langsung dengan aktivitas ekowisata hutan desa. Kegiatan edukasi yang dilaksanakan dengan ceramah, diskusi, pendampingan terkait manajemen kewirausahaan BUMDes pengelola hutan desa sebagai basis pariwisata di Desa Galungan mampu meningkatkan kompetensi manajemen sektor public seperti halnya BUMDesa di Bali.

\section{METODE}

Kegiatan pengabdian kepada masyarakat ini merupakan hilirisasi hasil penelitian yang dilaksanakan pada tahun 2020 (Wahyuni \& Sara, 2020). Tujuan pengabdian adalah upaya peningkatan manajemen kewirausahaan BUMDes unit pengelolaan ekowisata hutan desa yang dilaksanakan dengan memberikan pelatihan dan pendampingan. Pelaksanaan kegiatan pengabdian ini menggunakan metode partisipatif yang memungkinkan tim pengabdian berinteraksi, berkomunikasi secara intensif dan langsung dengan masyarakat serta aktivitas usaha mereka. Survey berupa wawancara secara mendalam, penelusuran dokumen, dan observasi lapangan dalam rangka memperoleh informasi dari pihak-pihak yang berkompetensi memberikan data dan informasi.

Pengabdian dilaksanakan selama 4 kali selama satu bulan dengan metode ceramah tanya jawab, brainstorming, small group discussion (SGD) (Astawa, Suarja, \& Sukawati, 2021). Wawancara dilakukan pada informan seperti pengelola ekowisata dalam hal ini BUMDesa Galungan, aparat desa, desa adat, dan pemangku kepentingan yang terlibat langsung dengan aktivitas ekonomi, sosial dan lingkungan ekowisata. Pertama, tahap persiapan, tim pengabdi mengidentifikasi permasalahan mitra dan menyusun jadwal kegiatan pengabdian kepada masyarakat. Kedua, tim mengurus perijinan ke Kantor Desa untuk melaksanakan kegiatan di desa mereka. Ketiga, mengidentifikasi peserta/responden. Keempat, melakukan survey, wawancara, dan observasi dengan responden dengan mengunjungi mereka satu per satu untuk bekerjasama, Kelima, membuat janji pertemuan dan melakukan temu muka secara formal untuk menentukan objek yang dijadikan fokus kajian yaitu manajerial BUMDes, kepala desa, ketua adat, dan pihak yang terlibat langsung dengan aktivitas ekowisata hutan desa (pokdarwis). Keenam, melengkapi data hasil survey. Ketujuh, melaksanakan small group discussion (SGD) dengan melibatkan praktisi seperti aparat desa mengenai strategi penguatan sumber daya manusia (SDM) dan kelembagaan BUMDes konteks ekowisata. Kedelapan, pelatihan, di mana pada setiap kegiatan dilaksanakan teknik pengumpulan data dan evaluasi kegiatan yaitu test (pre test dan post test) untuk memahami dan mengevaluasi pemahaman peserta pengabdian.

Kegiatan melibatkan 15 partisipan terdiri atas pengelola, manajer BUMDes ekowisata, pemandu wisata hutan desa, kepala desa, desa adat, instansi/lembaga lain yang terlibat dalam pengelolaan ekowisata hutan desa, serta petani peternak madu yang memanfaatkan kawasan hutan sekitar. Dari survey, penelitian mereduksi, menyajikan data dan kesimpulan. Kegiatan pengabdian telah dilaksanakan di aula pertemuan kawasan 
ekowisata hutan desa, ruang pertemuan BUMDes, dan balai Desa Galungan. Kesuksesan target capaian meliputi beberapa indikator di antaranya: (1) indikator peningkatan karakteristik kewirausahaan; (2) indikator peningkatan keterampilan manajemen pelaku usaha. Materi pelatihan meliputi topik manajemen kewirausahaan seperti keterampilan manajemen sumber daya manusia (SDM), keterampilan operasional \& teknik, keterampilan manajemen finansial serta keterampilan individu (Mamabolo et al., 2017); (MacíasJiménez, Acosta-Fontalvo, \& Jiménez-Barros, 2019).

\section{HASIL KARYA UTAMA DAN PEMBAHASAN}

Penguatan ekonomi pedesaan mampu tercapai melalui manajemen kewirausahaan ekowisata hutan desa oleh BUMDEs. Survey awal menemukan bahwa BUMDesa Galungan selaku pengelola ekowisata hutan desa belum mampu menerapkan manajemen dalam praktik usaha namun dengan teknik yang relatif monoton tanpa inovasi sesuai perkembangan ilmu pengetahuan. Manajemen BUMDEs dan pelaku usaha ekowisata membutuhkan dukungan pelatihan untuk memperkuat kompetensi dalam persaingan bisnis. Berdasarkan observasi, masih ditemukan pengelolaan ekowisata hutan desa oleh BUMDes, pemandu wisata dan pemangku kepentingan dengan pengelolaan sederhana, masih belum mengoptimalkan konsep dan teori manajemen pada pengusaha sektor publik seperti BUMDes ini.

Salah satu solusinya adalah melatih pengelola BUMDes dan pemangku kepentingan agar mampu menunjukkan sikap perilaku manajemen. Pelatihan praktik manajemen memberikan pemahaman proses manajemen, perencanaan organisasi, manajemen informasi, dan jaminan kualitas untuk menghadapi tantangan bisnis dan kompetensi (Talib, Ali, \& Idris, 2014).

Secara umum, kegiatan PKM ini berjalan dengan baik. Sasaran PKM yaitu pengelola BUMDes ekowisata dan pemangku kepentingan menunjukkan antusiasme dan semangat dalam mengikuti beberapa kegiatan pelatihan dan pendampingan. Mereka terlibat dalam diskusi yang terkait dengan berbagai permasalahan yang dihadapi di lapangan, terkait dengan konteks kegiatan tim PKM. Temuan kegiatan pengabdian ini menunjukkan bahwa setelah pengabdian ada perubahan perilaku manajemen yang meningkat. Mitra pengabdian masyarakat yaitu manajemen BUMDes dan pemangku kepentingan (pokdarwis) ekowisata, kepala desa, ketua desa adat lebih memahami prinsip-prinsip dan konsep manajemen bisnis, manfaat manajemen, dan langkah praktis mengelola BUMDes berbasis ekowisata hutan desa. Mitra menunjukkan tingkat keterlibatan aktif dengan pembagian tugas menyediakan sarana prasarana untuk suksesnya kegiatan, bersama tim merancang jadwal kegiatan. Di samping itu, peserta aktif bertanya tentang maksud dan tujuan; dan hasil dari edukasi \& praktik manajemen.

Secara detail, pada bagian ini diuraikan mengenai peningkatan pemahaman, pengetahuan, dan keterampilan peserta setelah mengikuti pelatihan, yaitu sebagai berikut:

\section{A. Keterampilan manajemen sumber daya manusia BUMDes pengelola ekowisata}

Kegiatan pertama pelatihan adalah presentasi dengan topik keterampilan manajemen sumber daya manusia yang menjelaskan tentang pentingnya keterampilan sebagai bagian dari kompetensi SDM. Kegiatan awal pelatihan ini mencatat hasil pre-test keterampilan SDM diperoleh angka 25\%, sedangkan hasil post-test meningkat menjadi $75 \%$. Ada peningkatan pengetahuan dan keterampilan mengelola sumber daya manusia dan 
pemahaman konsep manajemen sumber daya manusia. Pengetahuan yang meningkat mendorong sikap, keterampilan SDM BUMDes dalam pengelolaan ekowisata hutan desa. Muncul perubahan perilaku peserta, di mana mereka mampu mendefinisikan tugas/pekerjaan, menilai kinerja karyawan secara keseluruhan, mengembangkan potensi karyawannya, mendelegasikan tugas, termasuk kemampuan menyelesaikan masalah pelanggan. Ciri-ciri kepribadian tersebut mampu mempengaruhi kemampuan individu melakukan kegiatan berlandaskan kewirausahaan sektor publik seperti BUMDes ini.

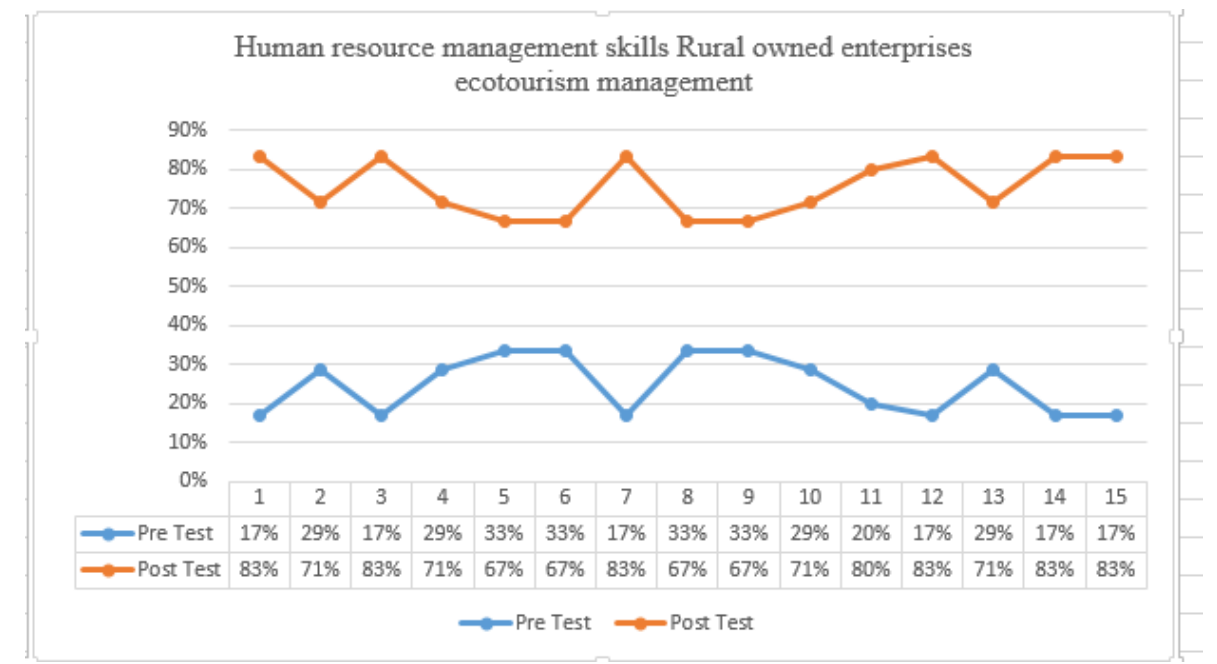

Diagram 1. Peningkatan keterampilan sumber daya manusia BUMDEs pengelola ekowisata

\section{B. Keterampilan manajemen operasional/teknikal BUMDEs pengelola ekowisata}

Setelah dilaksanakan pelatihan, ada peningkatan pemahaman dan keterampilan pengelola BUMDes dan pemangku kepentingan ekowisata hutan desa yang melibatkan ide, proses, dan teknik dalam operasional. Pada pelatihan kedua, diperoleh hasil pre-test sebesar $26 \%$ dan post-test sebesar $74 \%$, menunjukkan peningkatan keterampilan teknikal mengelola lembaga ekonomi BUMDEs ekowisata sebesar 48\% (lihat Diagram 2). Pembelajaran melalui ceramah, diskusi tema keterampilan teknikal atau pengelolaan operasional menguatkan keterampilan operasional seperti mampu mengelola operasional perusahaan dengan tetap mempertimbangkan budaya lokal; berani berkomunikasi menyampaikan informasi, komunikasi secara lisan dan tertulis; menjelaskan tahapan operasional ekowisata, kemampuan mengelola jasa layanan; keterampilan membuat jadwal kegiatan tur sesuai dengan alokasi waktu yang telah ditetapkan; dan kemampuan melakukan audit kualitas untuk mengevaluasi apakah produk/layanan sudah mematuhi norma atau standar industri (termasuk standar industri pariwisata). Keterampilan operasional juga termasuk upaya menciptakan brand ekowisata Galungan, madu hutan Galungan, modifikasi layanan sesuai permintaan klien dan peraturan pemerintah (misal: mematuhi protokol kesehatan terkait covid-19), menggunakan media sosial untuk mengiklankan ekowisata hutan desa berbasis lingkungan (planet), ekologi, sosial (manusia), dan ekonomi; serta memanfaatkan teknologi dalam distribusi layanan pariwisata. Misalnya memanfaatkan internet untuk distribusi produk/layanan dan pemasaran digital sehingga mampu menjangkau pasar secara global. 


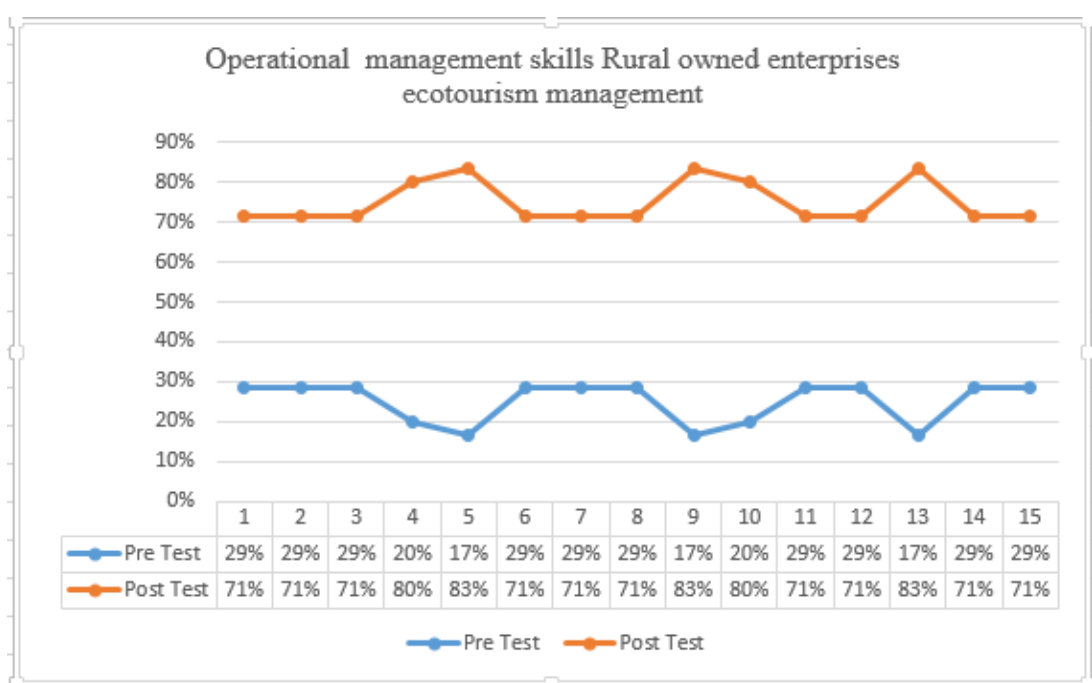

Diagram 2. Peningkatan keterampilan manajemen operasional BUMDes pengelola ekowisata hutan desa

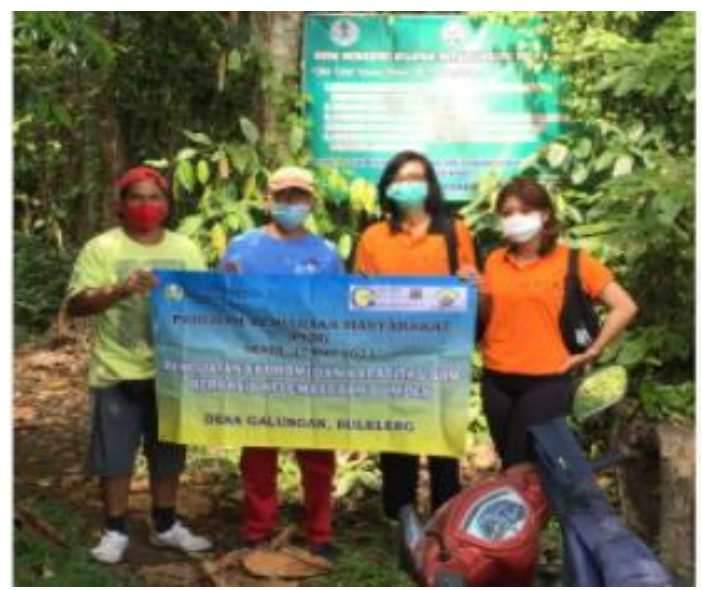

Gambar 1. Observasi operasional ekowisata hutan Desa Galungan

\section{Keterampilan manajemen keuangan BUMDes pengelola ekowisata}

Kegiatan ketiga yaitu, praktik keterampilan manajemen keuangan yang memberikan gambaran fungsi manajemen keuangan yaitu mengalokasikan dana dan mencari sumbersumber dana (misal dari keuntungan dan modal awal). Hasil pre-test aspek keterampilan manajemen keuangan sebesar $21 \%$, dan hasil analisis statistik deskriptif post-test sebesar $79 \%$, menunjukkan peningkatan keterampilan mengelola keuangan lembaga ekonomi sebesar $58 \%$.

Setelah pelaksanaan kegiatan pelatihan ini, ada perubahan sikap dan perilaku mengelola uang tunai organisasi secara benar, memahami aliran uang masuk dan uang keluar, menghitung biaya, mengarsip laporan pajak, dan membuat pembukuan serta menghasilkan laporan keuangan berupa daftar neraca \& laporan laba rugi mencerminkan keterampilan manajemen keuangan BUMDEs pengelola ekowisata hutan Desa Galungan. 


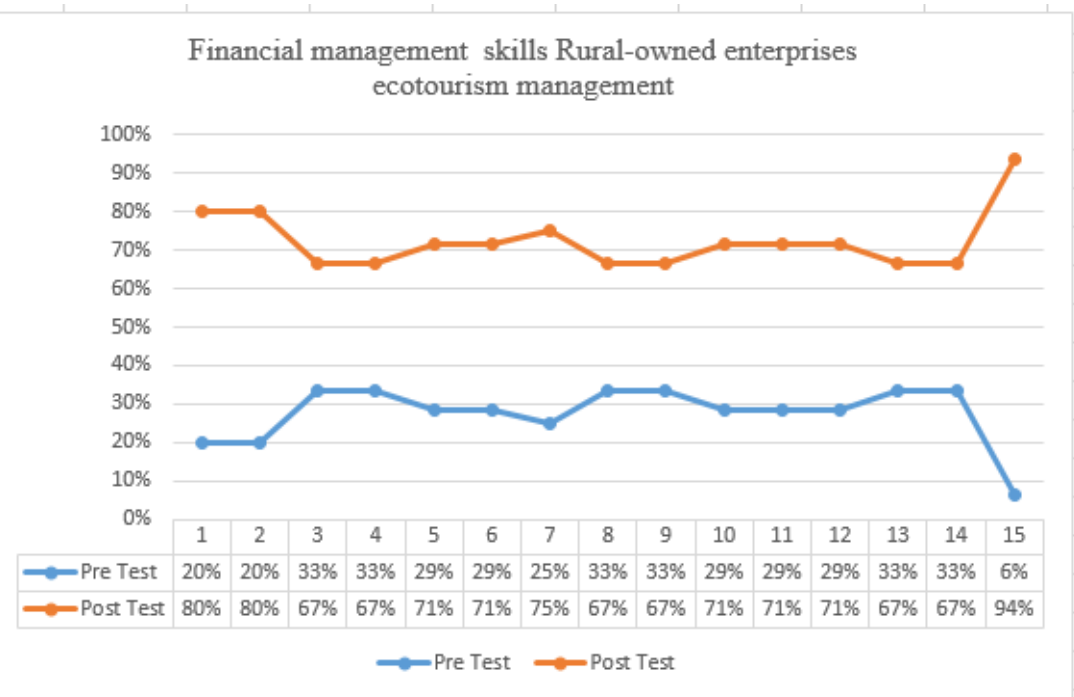

Diagram 3. Peningkatan keterampilan manajemen keuangan pada BUMDes pengelola ekowisata hutan desa

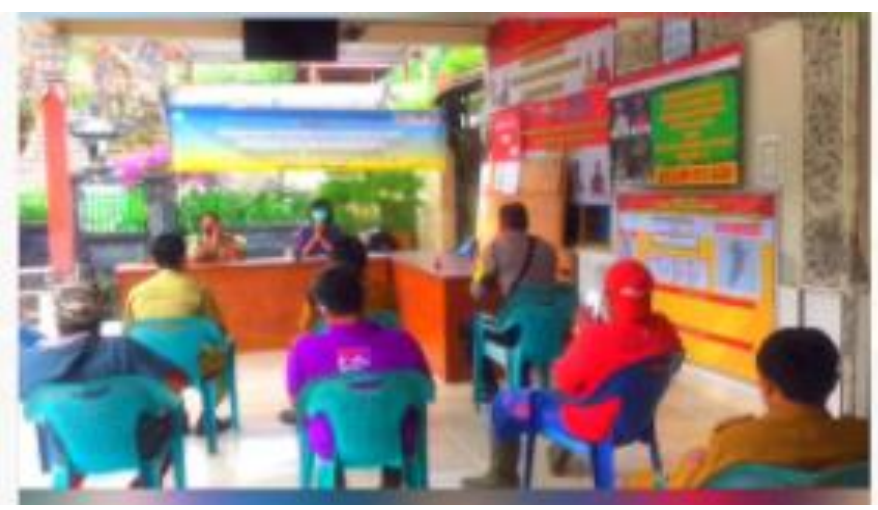

Gambar 2. Diskusi penguatan manajemen kewirausahaan BUMDes ekowisata

\section{Keterampilan personal BUMDes pengelola ekowisata}

Kegiatan pengabdian tahap keempat yaitu menguatkan keterampilan pribadi dalam upaya mendukung perkembangan usaha. Pelaksanaan pelatihan kali ini mampu memperkuat niat dan aktivitas manajemen BUMDes ekowisata hutan Desa Galungan dalam menggunakan kekuatan batin/spiritual dalam menjalankan wirausaha, mereka mampu secara iklas bekerja berjam-jam sebagai bagian dari keterampilan personal, dan nilai budaya dan proses kewirausahaan.

Dalam PKM ini dilakukan pengukuran dengan analisis statistik deskriptif dengan pretest memperoleh hasil sebesar $30 \%$, dan hasil post-test sebesar $70 \%$, dan hasil menunjukkan, meningkatnya pemahaman dan keterampilan manajemen dan kewirausahaan sebesar $40 \%$ (lihat Diagram 4). Kemampuan membentuk hubungan dan berinteraksi dengan orang lain, mampu bekerja keras, mampu memotivasi dan menguatkan diri untuk bekerja dan melayani (karyawan lain dan pelanggan), dan keterampilan memimpin diri sendiri sebagai bentuk keterampilan personal. 


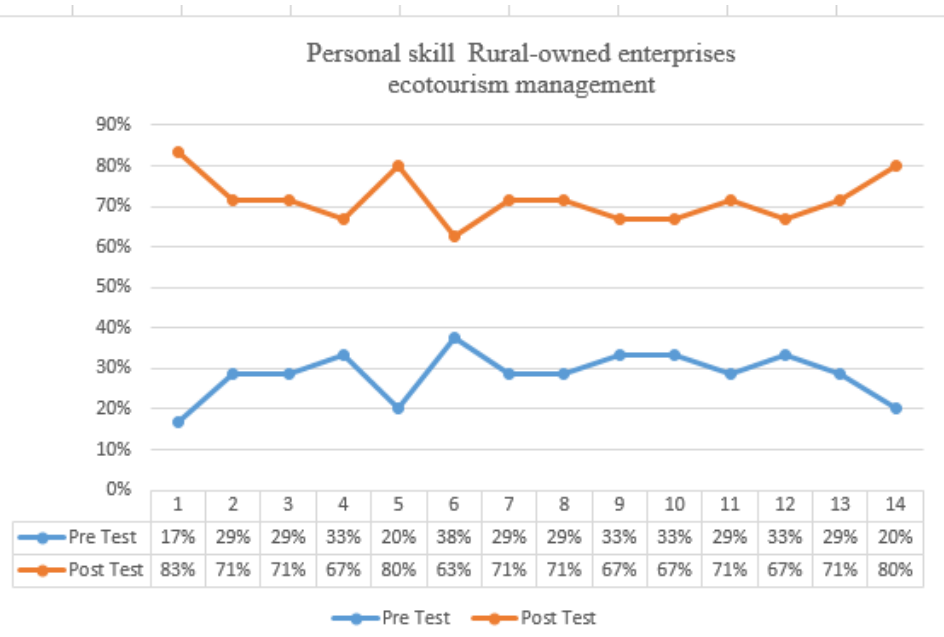

Diagram 4. Peningkatan keterampilan personal pada BUMDes pengelola ekowisata hutan desa

Karakteristik kewirausahaan menguatkan implementasi praktik manajemen : mandiri, otonomi, kepemimpinan efektif, kebutuhan untuk berprestasi; kesediaan memeriksa lingkungan internal untuk mencapai tujuan terbaik; cenderung mengambil keputusan yang inovatif. Secara umum, mitra pengabdian dalam hal ini pengelola BUMDes Galungan , perangkat desa selaku penasehat BUMDes menunjukkan minat dan antusias yang tinggi, ditunjukkan dengan kontribusi mereka pada penyediaan fasilitas tempat kegiatan beserta perangkat kegiatan: meja, kursi, spanduk, dan penyediaan konsumsi untuk peserta.

\section{KESIMPULAN}

Berdasarkan hasil evaluasi pelaksanaan pengabdian, dapat disimpulkan bahwa kegiatan pengabdian ini telah berhasil dilaksanakan dengan tingkat kesuksesan yang tinggi. Manajer dan pengelola BUMDEs selaku lembaga usaha desa, parat desa, desa adat, pemandu wisata yang bersama-sama peduli dan bertanggung jawab atas kegiatan ekowisata di Desa Galungan dapat dengan efisien mempraktikkan manajemen kewirausahaan sesuai bidang tugas masing-masing. Keterampilan manajemen kewirausahaan seperti keterampilan mengelola SDM, keterampilan manajemen keuangan, keterampilan pribadi, dan manajemen teknis/operasional ini diharapkan dapat dipraktikkan di Desa Galungan untuk mencapai kinerja usaha ekowisata secara berkelanjutan. Sebagai bentuk pertanggungjawaban pengelola BUMDes kepada pemerintah yang telah memfasilitasi pendirian BUMDes, ke depan, pengetahuan dan keterampilan manajemen berbasis kewirausahaan harus terus ditingkatkan demi pembangunan BUMDes berkelanjutan berbasis sosial, lingkungan dan keuntungan ekonomi masyarakat desa dan lokal.

\section{UCAPAN TERIMA KASIH}

Saya mengucapkan terima kasih kepada: (1) Rektor Universitas Warmadewa atas ruang, dukungan moril dan hibah institusi dalam pelaksanaan darma pengabdian kepada masyarakat tahun 2021. (2) Kepala LPM Universitas Warmadewa yang telah memberikan informasi, kesempatan, dan persetujuan kegiatan pengabdian, sehingga kegiatan pengabdian kepada masyarakat dapat terlaksana sesuai rencana kegiatan; (3) Kepala Desa, 
PEDULI: Jurnal Ilmiah Pengabdian Pada Masyarakat, 2021, Vol.5, No.2 ISSN: 25974653. EISSN:25974688 http://peduli.wisnuwardhana.ac.id/index.php/peduli/index

pengelola BUMDesa, pemangku kepentingan di Desa Galungan atas keterlibatan dan semangatnya berpartisipasi dalam pelatihan ini.

\section{DAFTAR PUSTAKA}

Agunggunanto, E. Y., Arianti, F., Kushartono, E. W., \& Darwanto. (2016). Pengembangan Desa Mandiri Melalui Pengelolaan Badan Usaha Milik Desa (BUMDes). Jurnal Dinamika Ekonomi \& Bisnis, 13(1), 67-81.

Agunggunanto, E. Y., Arianti, F., Kushartono, E. W., \& Darwanto. (2016). Pengembangan Desa Mandiri Melalui Pengelolaan Badan Usaha Milik Desa (BUMDes). Jurnal Dinamika Ekonomi \& Bisnis, 13(1), 67-81.

Aryaningsih, N. N., Suari, P. R. W., Darmayasa, N., \& Utthavi, W. H. (2021). Management Model of Rural-Owned Enterprises Based on Entrepreneurship Innovation as a Tourist Attraction. Proceedings of the International Conference on Applied Science and Technology on Social Science (ICAST-SS 2020), 544, 121-125. https://doi.org/10.2991/assehr.k.210424.024

Astawa, I. P., Suarja, I. K., \& Sukawati, T. G. R. (2021). Exploring Green Start-up Finance for Tourism Villages. Proceedings of the International Conference on Applied Science and Technology on Social Science (ICAST-SS 2020), 544, 82-85. https://doi.org/10.2991/assehr.k.210424.017

Costanza, F. (2019). Stimulating new business creation through system dynamics education. Journal of Economic and Administrative Sciences, 35(4), 267-284. https://doi.org/10.1108/jeas-10-2018-0112

Doran, J., McCarthy, N., \& O'Connor, M. (2018). The role of entrepreneurship in stimulating economic growth in developed and developing countries. Cogent Economics and Finance, 6(1), 1-15. https://doi.org/10.1080/23322039.2018.1442093

Febryani, H., Nurmalia, R., Lesmana, I. M. I., Ulantari, N. K. W., Dewi, D. P. Y. P., \& Rizky, N. (2019). Keberadaan Badan Usaha Milik Desa (Bumdes) Sebagai Penguatan Ekonomi Desa Abiantuwung. Jurnal Ilmiah Akuntansi Dan Humanika, 8(1), 95-103. https://doi.org/10.23887/jinah.v8i1.19865

Fennimore, A., \& Sementelli, A. (2016). Public entrepreneurship and sub-clinical psychopaths: a conceptual frame and implications. International Journal of Public Sector Management, 29(6), 612-634. https://doi.org/10.1108/IJPSM-01-2016-0011

Gangi, Y. A. (2017). The role of entrepreneurship education and training on creation of the knowledge economy. World Journal of Entrepreneurship, Management and Sustainable Development, 13(4), 375-388. https://doi.org/10.1108/wjemsd-06-20170032

Ionescu, V. (2016). Entrepreneurship, Management and Leadership. An Organizational Perspective. Revista de Management Comparat Internațional, 17(5), 477-486.

Jayawarna, D., Macpherson, A., \& Wilson, A. (2007). Training commitment and performance in manufacturing SMEs: Incidence, intensity and approaches. Journal of Small Business and Enterprise Development, 14(2), 321-338. https://doi.org/10.1108/14626000710746736

Kuncoro, M., \& Cahyani, D. (2018). Performance of social forestry on farmers' revenues: lessons from Yogyakarta and Lampung, Indonesia. The Business \& Management Review, 9(4), 275-289. 
Macías-Jiménez, M. A., Acosta-Fontalvo, L. C., \& Jiménez-Barros, M. A. (2019). Document management practices in SMEs: An information management capabilitybased approach. Records Management Journal, 30(1), 63-79. https://doi.org/10.1108/RMJ-10-2018-0042

MacPherson, A., \& Jayawarna, D. (2007). Training approaches in manufacturing SMEs: Measuring the influence of ownership, structure and markets. Education and Training, 49(8-9), 698-719. https://doi.org/10.1108/00400910710834102

Mamabolo, M. A., Kerrin, M., \& Kele, T. (2017). Entrepreneurship management skills requirements in an emerging economy: A South African outlook. The Southern African Journal of Entrepreneurship and Small Business Management, 9(1), 10. https://doi.org/10.4102/sajesbm.v9i1.111

Nuranita, N., Dassir, M., \& Makkarennu, M. (2020). Dinamika Kelompok Tani Hutan Desa (KTHD) Bontomarannu Di Desa Labbo, Kecamatan Tompobulu, Kabupaten Bantaeng. Jurnal Hutan Dan Masyarakat, 12(1), 78. https://doi.org/10.24259/ jhm.v12i1.9895

Poon, P. S., Zhou, L., \& Chan, T. S. (2009). Social entrepreneurship in a transitional economy: A critical assessment of rural Chinese entrepreneurial firms. Journal of Management Development, 28(2), 94-108. https://doi.org/10.1108/02621710910932061

Sardianou, E., Kostakis, I., Mitoula, R., Gkaragkani, V., Lalioti, E., \& Theodoropoulou, E. (2016). Understanding the entrepreneurs' behavioural intentions towards sustainable tourism: a case study from Greece. Environment, Development and Sustainability, 18(3), 857-879. https://doi.org/10.1007/s10668-015-9681-7

Sastri, I., Irianto, I. K., \& Wahyuni, N. M. (2021). Strengthening Institutions and Human Resources in the Lemukih Village Business Unit. Ijbel.Com, 24(4), 8-14. Retrieved from https://www.ijbel.com/wp-content/uploads/2021/06/IJBEL24-702.pdf

Talib, H. H. A., Ali, K. A. M., \& Idris, F. (2014). Critical success factors of quality management practices among SMEs in the food processing industry in Malaysia. Journal of Small Business and Enterprise Development, 21(1), 152-176. https://doi.org/10.1108/JSBED-10-2013-0162

Thassanabanjong, K., Miller, P., \& Marchant, T. (2009). Training in Thai SMEs. Journal of Small Business and Enterprise Development, 16(4), 678-693. https://doi.org/10.1108/14626000911000992

Wahyuni, N. M., \& Sara, I. M. (2020). The effect of entrepreneurial orientation variables on business performance in the SME industry context. Journal of Workplace Learning, 32(1). https://doi.org/10.1108/JWL-03-2019-0033

Zampetakis, L. A., \& Moustakis, V. (2007). Fostering corporate entrepreneurship through internal marketing: Implications for change in the public sector. European Journal of Innovation Management, 10(4), 413-433. https://doi.org/10.1108/ 14601060710828754 